\title{
THE MILWAUKEE POLLUTION CASE - IMPLICATIONS FOR WATER RESOURCES PLANNING ${ }^{1}$
}

\author{
Michael Donovan, Charles A. Job, and William C. Sonzogni ${ }^{2}$
}

\begin{abstract}
The Ilinois v. Milwaukee Federal District Court decision is the most far reaching application yet of the federal common law of nuisance to interstate water pollution conflicts. Although a Federal Appelate Court recently rescinded part of the district court decision, Milwaukee must still upgrade its metropolitan sewage system to a level beyond that required by federal and state regulations. The improvements must be completed with or without federal aid. The case points out the apparent inability of the Clean Water Act, the most comprehensive federal legislation affecting the nation's water quality, to deal with certain interstate water quality conflicts. The Milwaukee decision could set a precedent for similar settlements elsewhere which may in turn affect the U.S. Environmental Protection Agency's water quality clean up program. A more integrated, ecosystem conscious approach to management of shared water resources (e.g., the Great Lakes) would help reduce the need for court decisions like Ilinois v. Milwaukee. (KEY TERMS: Milwaukee pollution; Great Lakes; water resources planning; combined sewer overflow; nuisance law; environmental law; water quality; water pollution control; environmental economics; ecosystem; Clean Water Act.)
\end{abstract}

\section{INTRODUCTION}

In 1969 Illinois first brought suit in federal court against the City of Milwaukee for allegedly creating a public nuisance by discharging raw or insufficiently treated sewage into Lake Michigan. Since then there have been four court decisions, and the matter has not yet been fully resolved. In a 1972 decision the U.S. Supreme Court ruled that the federal common law of nuisance was applicable to interstate water quality conflicts. A 1977 Federal District Court decision ruled that Milwaukee must adopt a sewage control program much stricter and more costly than required under existing federal and state statutes. A recent Federal District Court decision partly rescinded the 1977 order, but left Milwaukee with the task of completely eliminating its combined sewer overflow (CSO) by 1989. Currently, the case is pending before the U.S. Supreme Court (the Court has not yet decided whether to hear arguments on the case).

If the Milwaukee decision is upheld, the application of federal common law of nuisance may affect those in compliance with federal regulations, as well as those that are not. More importantly, the decision, if upheld by the U.S. Supreme
Court, may require changes in current U.S. Environmental Protection Agency (EPA) regulations, and, by implication, could represent a challenge to the policies expressed in parts of the Clean Water Act (CWA).

This paper describes the circumstances under which common law was applied in Illinois $v$. Milwaukee, and assesses the potential future effects of the decision in the Great Lakes region.

\section{MILWAUKEE'S LAKE MICHIGAN POLLUTION CONTROL SITUATION}

Pollution from Milwaukee's municipal waste water effluent and CSO has been a recognized problem since at least the mid-1950's. At that time separation of combined sewer to control overflows was recommended (Milwaukee River Technical Study Committee, 1968). The estimated cost at that time for sewer separation was $\$ 127$ million. In 1966 the city again studied the problem, and a more extensive program was proposed at a cost of $\$ 300$ million (Milwaukee River Technical Study Committee, 1968). Although Milwaukee has had an ongoing program to expand and improve its sewerage system, the quality of treated effluent has lagged somewhat behind that required by federal regulations. Milwaukee's sewage effluent still does not meet the requirements of the CWA, notwithstanding the more stringent requirements imposed by the Illinois suit.

The Milwaukee Metropolitan Sewerage District (MMSD), serving an area of approximately $1,087 \mathrm{~km}^{2}$, treats an average of $24210^{3} \mathrm{~m}^{3} /$ day $(64 \mathrm{mgd})$ of sewage, with peak volume (not counting overflows) of $3,02510^{3} \mathrm{~m}^{3} /$ day $(800 \mathrm{mgd})$ (R. Thielke, Milwaukee Metropolitan Sewerage District, personal communication, 1979). The treatment plants have of ten been unable to meet the current Wisconsin effluent standard of $30 \mathrm{mg} / \mathrm{L}$ biochemical oxygen demand (BOD) and $30 \mathrm{mg} / \mathrm{L}$ suspended solids (SS) (Ward, 1978). The effluent also annually contributes about $200 \mathrm{~kg}$ of phosphorus to Lake Michigan, not counting the contribution from CSO (Great

\footnotetext{
${ }^{1}$ Paper No. 80073 of the Water Resources Bulletin. Discussions are open until October 1, 1981.

${ }^{2}$ Respectively, Research Assistant, Basin Plan Program Manager, and Staff Scientist, Great Lakes Basin Commission Staff, Great Lakes Basin Commission, 3475 Plymouth Road, P. O. Box 999, Ann Arbor, Michigan 48106. (Donovan is currently a Law Student at University of Michigan Law School, Lawyers Club, 551 South State Street, Ann Arbor, Michigan 48109.) (The findings in this paper are the authors' and do not necessarily reflect those of the Great Lakes Basin Commission.)
} 
Lakes Water Quality Board, 1979). Comparatively, the total annual phosphorus load to Lake Michigan is about 7,000 metric tons/yr. Direct municipal dischargers, such as Milwaukee, annually contribute about 1,800 metric tons per year, or about 25 percent of the total annual load (Chapra and Sonzogni, 1979). Hence, Milwaukee's sewage effluent contributes about three percent of the total load of phosphorus to Lake Michigan and about 10 percent of the municipal point source load.

Storm sewer flow from the $70 \mathrm{~km}^{2}$ of the Milwaukee metropolitan area served by combined sewers frequently causes volume overloads at the Milwaukee treatment plants (R. Thielke, Milwaukee Metropolitan Sewerage District, personal communication, 1979). As a result, quantities of untreated effluent (sewage plus storm water) are discharged into Lake Michigan. These discharges have not generally been thought to cause lakewide problems, although localized pollution problems in the Milwaukee harbor area have been noted (Bothwell, 1977; Great Lakes Water Quality Board, 1977; Sonzogni, et al., 1979).

\section{THE LEGAL CASE AGAINST MILWAUKEE}

\section{Federal Common Law of Nuisance}

The doctrine of nuisance constitutes a major root of environmental law and has been employed in the abatement of pollution for centuries (Rodgers, 1977; Tarlock, 1979). Since nuisance is a common law concept, its meaning cannot be drawn from statutes. Instead, it has been fashioned judicially from principles found in the decisions of the courts.

Public nuisance is generally defined as an unreasonable interference with a right common to the general public. If the conduct is of a continuing nature or has long lasting effects, a court ordered injunction can be a possible remedy. To obtain an injunction in advance of actual injury, substantial harm need only be threatened. No actual harm need have occurred.

In Illinois v. Milwakee (1979) the court adopted a very simple definition of nuisance: "The elements of a claim based on the federal common law of nuisance are simply that the defendant is carrying on an activity that is causing an injury or significant threat of injury to some cognizable interest of the complainant" (599 F.2d 151, 165).

However, federal courts are limited in their authority to use common law; thus, under federal law the doctrine of nuisance may only be applied under certain conditions. The scope of these conditions has evolved slowly, based on the leading case of Erie R. Co. v. Tompkins in 1938. Here the Supreme Court limited the use of common law to areas of federal concern (304 U.S. 64). Subsequent decisions have explained the meaning and application of this decision and described some particular situations in which federal common law may be applied.

In 1971 a Federal Appellate Court decided a case similar to Illinois v. Milwaukee. The case, Texas v. Pankey involved a number of communities in Texas which sought to enjoin ranchers in New Mexico from using a certain insecticide on their land. Texas claimed that use of the chemical was a public nuisance because it threatened the water supply of downstream communities. The court held that common law could be applied to the case, and remanded it to Federal District Court for further proceedings (411 F.2d 236).

In 1972 Illinois took its complaint against Milwaukee directly to the U.S. Supreme Court under the provision of the Constitution giving the Supreme Court original jurisdiction in all cases in which a state is a Party (Illinois $\nu$. Milwaukee, 406 U.S. 91). The court affirmed the Texas v. Pankey decision and held that the federal common law of nuisance could be applied to interstate water pollution conflicts.

In Illinois v. Milwaukee (1972) the Supreme Court explained that the development of federal common law was supported by government policies in the National Environmental Policy Act (NEPA), the Fish and Wildife Coordination Act, and especially the Federal Water Pollution Control Act (FWPCA) of 1965 which states, "It is the policy of the Congress to recognize, preserve, and protect the primary responsibilities and rights of states to reduce and eliminate pollution, (and) to plan the development and use ... of land and water resources." The Court cited the need for uniformity of rules in matters of interstate water quality and that "a state with high water quality standards may insist that its strict standards be honored, and that it not be compelled to subjugate itself to the more degrading standards of a neighbor" (406 U.S. 91 at 107). The court also asserted that new federal laws and regulations may in time preempt the field of federal common law of nuisance.

After the passage of the 1972 Amendments to the FWPCA, Milwaukee went back to court to argue that these Amendments preempted federal common law. However, in 1973 the Federal District Court held that the 1972 Amendments did not preempt the State of Illinois from seeking abatement under federal common law (Illinois v. Milwaukee, 366 F Supp. 298). Specifically, the court cited Section 510 of the Act which states". . nothing in this Act shall ... be construed as impairing or in any manner affecting any right or jurisdiction of the states with respect to the waters (including boundary waters) of such states."

The 1972 Illinois decision did not determine the extent of Federal common law jurisdiction for pollution cases. In City of Evansville v. Kentucky Liquid (1979) the seventh circuit extended the Illinois decision to a case in which the plaintiff was a group of cities instead of a state. The case involved three cities in Indiana which sued a corporation and a sewage district in Kentucky for discharging pollutants into the Ohio River (604 F.2d 1008). However, in Committee for Jones Falls Sewage System v. Train (1976) the fourth circuit refused to extend Illinois $v$. Milwakee to an action by an association of community organizations and citizens in which there was no interstate effect (539 F.2d 1006). Future cases may define more precisely the limits of the federal court's jurisdiction to apply to common law of nuisance to water pollution conflicts. 


\section{Milwakee Decision and the 1979 Appeal}

In early 1977 a Wisconsin court required Milwaukee to adopt a program to meet the state effluent standards. A federal district court in July 1977 required Milwaukee to treat its sewage so that the five-day BOD and suspended solids concentrations do not exceed $5 \mathrm{mg} / \mathrm{L}$ ( $5 / 5$ standard), a level well beyond state requirements. In addition, the city was required to eliminate its CSO for a storm equal to the worst recorded over the last 37 years. Milwaukee appealed the decision. In April 1979 a Federal Court of Appeals decision rescinded the $5 / 5$ ruling, but left the $\mathrm{CSO}$ requirement in effect.

Illinois alleged that sewage from overflows and insufficiently treated sewage from Milwaukee's two treatment plants was causing a health hazard to the residents of Illinois, both by polluting its swimming beaches and by contaminating its water supply. To prove these claims they attempted to show that pathogens were being discharged by Milwaukee, and that they were transported to Illinois in sufficient numbers to pose a threat to the residents of Illinois. However, data were apparently not available to conclusively prove that discharge from Milwaukee's plants, during overflows or otherwise, was creating a hazard due to the presence of pathogens.

Regarding transport, part of Illinois' claim was that Illinois' waters could be polluted as Milwaukee's effluent is transported south. However, no direct evidence, such as actual bacteria counts, was presented of such pollution transport. South flowing currents which would be required to transport pollution from the Wisconsin coast to the Illinois coast, actually occur only infrequently during the summer (Monahan and Pelgrim, 1975). Nevertheless, the court concluded that pollution containing viable pathogens could reach Illinois beaches and drinking water intakes, including those of the City of Chicago.

In deciding the case in Illinois' favor, the court granted what is known as anticipatory relief. It was not proven that Milwaukee's effluent was causing illness to Illinois residents, but such proof was not necessary since the hazard was judged sufficiently severe to threaten damage or physical injury (Rodgers, 1977). Anticipatory relief has been granted in similar environmental cases, such as U.S. v. Reserve Mining Corp. in 1974. In this case discharge of asbestos fibers into Lake Superior was determined to be a threat to the welfare of the people of Duluth, Minnesota, and Superior, Wisconsin, even though the hazard was impossible to quantify.

It was also charged that Milwaukee's effluent was contributing to the eutrophication or excess biological productivity of Lake Michigan. The judge was satisfied that there was convincing evidence that Milwaukee was a major source of phosphorus input into the lake and that phosphorus was the limiting nutrient in the lake in terms of biological production.

In deciding on the eutrophication charge, the judge asserted that the plaintiff must be thought of as all the people of Illinois and all its future residents. The damage Milwaukee was inflicting on the lake must be weighed against the rights of all those who will use the basin "for as long as this planet is inhabited by human beings." However, he did agree that the consequences of eutrophication, which in the case of Lake Michigan are mostly aesthetic, were not as threatening as that posed by pathogens in the water. Nevertheless, the consequences were deemed serious enough to be an enjoinable nuisance, especially when the countervailing right that is asserted is the right to discharge sewage into Lake Michigan (Illinois v. Milwaukee, 1977; court transcript).

Milwaukee appealed the District Court decision on two issues: (1) whether the injunction imposed on Milwaukee based on the federal common law of nuisance can be more stringent than the remedies available under the Clean Water Act, and (2) whether the evidence in the case supports the type of injunction imposed. Concerning the first question the Federal Court of Appeals held: "The imposition of effluent limitations more stringent than those required under the (Clean Water) Act, if necessary to prevent harm to a complaining party, is fully consistent with the Act" (599 F.2d 151, 162). On the second issue the court held that the evidence is sufficient to support only part of the remedy ordered by the district court. The Court reversed the stringent $5 / 5$ treatment requirement, ruling that Illinois was unable to show conclusively that such treatment would further reduce the risk to Illinois residents. However, the Court upheld the other requirement that Milwaukee eliminate its combined sewer overflows by 1989 (599 F.2d 151,177).

Milwaukee has appealed the Court of Appeals decision to the U.S. Supreme Court and review was granted in March 1980 (Bureau of National Affairs, 1980). The appeal is based on the same issues brought to the Court of Appeals and also some related issues. Milwaukee contends that the federal common law of nuisance should not apply when the threat of harm is theoretical, and the evidence does not show actual harm. Also, Milwaukee questions whether the trial court can refuse to consider costs and cost effective considerations in fashioning its remedy when federal statutory and administrative provisions establish federal policy requiring a cost effective approach to pollution control. The Supreme Court's decision may help clarify the relationship between federal common law and the current federal water pollution control program. A decision is not expected before 1981 .

\section{COST OF COMPLIANCE}

The court decision will place an economic burden on Milwaukee and its residents. To comply with the federal and state court orders, Milwaukee must have a final plan by early 1980 for a major expansion of the city's two treatment plants, a sludge management program, rehabilitation of existing sewers to eliminate clear water infiltration, and a program to control CSO (Milwaukee Metropolitan Sewage District, 1979a). By city estimates, the total cost of all these programs will be close to $\$ 1.3$ billion in 1978 dollars (Hagerty, 1979). The cost of sewer separation alone, which the city has recently decided to undertake, is $\$ 501$ million (Milwaukee Metropolitan Sewerage District, 1979b). The only assistance Milwaukee is eligible to receive is $\$ 20$ million a year under a state assistance 
program. No federal funds are forthcoming or contemplated at this time. Since the court orders require compliance regardless of the availability of federal or state aid, it is expected that property taxes may have to rise about 20 percent to provide the necessary revenue (Ward, 1978).

The lack of federal assistance is due in part to the federal funding allocation program set up under the CWA which involves a complex set of procedures designed to give priority to the most cost effective projects. Court suits will not raise a project's priority. Although states are given the authority to determine a priority list for federal grants under the CWA, the criteria used must be clearly delineated and applied consistently to all projects. In the case of Milwaukee, the court ordered sewer project could not be raised high enough on the priority list to receive funding without violating the consistency criteria.

The Federal Court of Appeals did consider the financial burden imposed on Milwaukee by citing the reluctance of Congress (in the CWA) to push municipalities beyond the limits of their resources. Even though the court held that Congress' position in the CWA does not mark the limits of the court's power in common law nuisance action, they felt that the policy underlying Congress' position should be given some deference. This was one of the reasons they rescinded the stringent $(5 / 5)$ treatment requirements, and the only point in which economics was considered in the case.

\section{IMPLICATIONS FOR WATER RESOURCES PLANNING}

Other cases have been decided on the basis of the federal common law of nuisance, but Illinois $v$. Milwakee is significant because treatment beyond that stipulated in existing regulations is required. The decision could conceivably have a major effect on current and future water pollution control programs.

Litigation under nuisance law focuses on the nuisance or hazard itself; consideration of regional consequences or cost effectiveness, while relevant to the court's decision, may not have as much influence as in implementing regional water pollution control programs. Also, the remedies for nuisance are limited to money damages or injunctions and thus cannot always be completely responsive to the problem.

Milwaukee's sewer overflow problem is serious, but not necessarily the most serious CSO problem in the region. In fact, Table 1 shows that the population served by combined sewers in Milwaukee is less than several other major urban areas. While population and area served do not necessarily indicate the severity of the CSO problem (the volume of CSO is related to highly variable meteorological events), they do give an indication of the potential for problems. Cleveland and Detroit have overflows of untreated sewage even during dry weather. Many of the urban areas (e.g., Buffalo, Rochester, and Toledo) have their CSO problems under study, however.

Chicago itself has CSO problems. Although most sewage effluent from the Chicago area is diverted out of the Great Lakes basin by reversing the flows of the Chicago and Calumet
River systems, at least once a year there usually is a back up into Lake Michigan as a result of high runoff. However, this discharge was not legally relevant to either Judge Grady's opinion in district court or to the federal appeals court order. Recently, Harrison, et al. (1979), have traced specific pollution episodes at Chicago's South Water Filtration Plant to combined sewer overflow into Illinois' Calumet River and the Indiana Harbor Canal. Under certain weather conditions, discharge from these inlets into Lake Michigan is transported north to Chicago's water intakes. Hence, at least some of Chicago's water intake problems can be traced to its own pollution problem.

TABLE 1. Cities in the Great Lakes Region With Combined Sewer Overflows (with CSO areas serving more than 25,000 persons).

\begin{tabular}{|c|c|c|c|}
\hline City & $\begin{array}{c}\text { CSO } \\
\text { Population } \\
\text { (1000's) }\end{array}$ & $\begin{array}{c}\text { CSO Area } \\
\left(\mathrm{km}^{2}\right)\end{array}$ & $\begin{array}{l}\text { Total Urban } \\
\text { Population } \\
\text { (1000's) }\end{array}$ \\
\hline $\begin{array}{l}\text { Chicago, IL } \\
\text { (CSO does not normally } \\
\text { discharge into Great Lakes) }\end{array}$ & 4,509 & 940 & 6,185 \\
\hline Detroit, MI & 1,917 & 790 & 3,971 \\
\hline Buffalo, NY & 943 & 138 & 1,086 \\
\hline Cleveland, $\mathrm{OH}$ & 670 & 195 & 1,960 \\
\hline Gary, IN (Chicago Metro) & 469 & 300 & 529 \\
\hline Milwaukee, WI & 370 & 72 & 1,253 \\
\hline Syracuse, NY & 317 & 55 & 375 \\
\hline Akron, $\mathrm{OH}$ & 254 & 38 & 542 \\
\hline Toledo, $\mathrm{OH}$ & 232 & 105 & 476 \\
\hline Fort Wayne, IN & 184 & 50 & 225 \\
\hline South Bend, IN & 176 & 147 & 265 \\
\hline Rochester, NY & 167 & 37 & 601 \\
\hline Erie, PA & 136 & 65 & 175 \\
\hline Utica, NY & 130 & 62 & 180 \\
\hline Saginaw, MI & 95 & 52 & 106 \\
\hline Lansing, MI & 85 & 36 & 230 \\
\hline Grand Rapids, MI & 67 & 20 & 352 \\
\hline Muskegon, MI & 50 & 28 & 105 \\
\hline Lima, OH & 48 & 26 & 70 \\
\hline Duluth, MN & 31 & 11 & 106 \\
\hline Duluth Metro, WI (Superior) & 30 & 13 & 33 \\
\hline Kenoslia, WI & 30 & 6 & 84 \\
\hline Racine, WI & 29 & 5 & 117 \\
\hline Bay City, MI & 25 & 12 & 129 \\
\hline
\end{tabular}

Source: U.S. EPA, 1978.

Few major CSO corrective measures have actually been im plemented in the Great Lakes region. CSO control is expen sive, especially if it involves sewer separation. If a major city like Detroit or Chicago was forced to separate their sewers, the cost would run well into the billions. Even with sewer separation, pollution inflow from storm water runoff will still occur, although raw sewage discharge is eliminated. The State of Michigan, for example, ranks combined sewer overflow as a secondary priority in its recent five-year strategy for water quality, solid, and hazardous waste programs (Michigan Department of Natural Resources, 1979). 
From an economic viewpoint, court decisions such as the one affecting Milwaukee can result in suboptimal and costly water quality management. In the case of regional water resources, such as the Great Lakes, a few areas may have to bear an undue proportion of pollution control costs. Further, federal water pollution laws, such as the CWA, do not give federal agencies (e.g., EPA) adequate direction for resolving interstate disputes, and provide few alternatives other than litigation (the fact that Illinois v. Milwaukee was an interstate dispute is not critical; a class action may have had the same effect). However, from a legal standpoint, the court appropriately limited its judgments to the basic right of the public to prevent others from subjecting them to undue hazards rather than considering economic or regional factors. These factors are perhaps not sufficiently considered in the current federal water pollution control laws. In the district court decision, Judge Grady stressed that Lake Michigan must be viewed as a resource common to many states, and needed by people for generations to come. But to adequately and cost effectively protect shared resources such as Lake Michigan, a more integrated, cooperative approach, which considers the total water resources system, is required. Such a need has in fact been recognized by legislators, who introduced a bill (S.1136) into the 96th Congress entitled the "Integrated Environmental Nuisance Act of 1979." The intent of this bill is to promote comprehensive approaches to management of environmental programs.

\section{SUMMARY}

The Lake Michigan water pollution case of Illinois $v$. Milwaukee, a lengthy litigation involving complex legal and environmental issues, has potential significance to water resources planning and management. Perhaps the most important aspects of the decisions and opinions in the case are: (1) the successful application of the federal common law of nuisance to an interstate water pollution problem where the pollution poses a possible threat rather than a proven hazard; (2) the treatment required by the court was beyond that stipulated by existing pollution control regulations; (3) that Milwaukee was required to improve its water pollution control program without regard to whether federal grants might be available; and (4) the minimal concern given to the cost effectiveness of the required action relative to other water pollution problems in the water system. The last two points were appropriately not considered in the court decisions, but are important from a water resources planning perspective.

While the effect of the Milwaukee decision on management and planning of Great Lakes or other shared water resources is not certain, it is clear that planners have a responsibility to consider all hazards and nuisances even though they may not be covered under existing water quality regulations. At the same time, public policy would suggest that priority should first be given to problems with the more serious consequences. To establish such priorities, a coordinated approach between federal, state, and local entities is required. Present statutes do not cover this adequately.

Great progress has been made in the last two decades in water pollution control, so that most of the obvious and relatively inexpensively controlled pollution problems have been addressed. Many of the pollution problems that face society today are complex, and given current economic realities, careful cost effectiveness analysis is required. Otherwise, pollution control efforts could be disastrously misdirected.

Finally, when dealing with a shared water resource like the Great Lakes, it is important to consider the entire ecosystem (i.e., the interacting elements of water, air, land, and biota, including man). While it cannot be expected that an ecosystem concept be fully incorporated in all environmental litigation, such a perspective needs to be more fully developed by federal, state, and local agencies responsible for planning and management. A more integrated, coordinated approach to managing and planning of shared water resources, based on an ecosystem framework which links human activities with nonhuman aspects of the ecosystem, would help avoid litigation such as Illinois v. Milwaukee.

\section{LITERATURE CITED}

Bothwell, M. W., 1977. Studies on the Distribution of Phytoplankton Pigments and Nutrients in the Milwaukee Harbor Area. Special Report No. 25, Center for Great Lakes Studies, University of Wisconsin, Milwaukee, Wisconsin, 93 pp.

Bureau of National Affairs, 1980. Milwaukee v. Illinois, No. 79-408. U.S. Law Week 48:3279.

Chapra, S. C. and W. C. Sonzogni, 1979. Great Lakes Total Phosphorus Budget for the Mid-1970s. JWPCF 51(10):2524-2533.

Great Lakes Water Quality Board, 1977. Great Lakes Water Quality Annual Report. International Joint Commission, Windsor, Ontario, $89 \mathrm{pp}$.

Great Lakes Water Quality Board, 1979. Inventory of Major Municipal and Industrial Point Source Dischargers in the Great Lakes Basin. International Joint Commission, Windsor, Ontario.

Hagerty, T. J., 1979. Sewer Cost Remains High Despite Easing of Burden. The Milwaukee Journal, April 27.

Harrison, W., D. L. McCown, K. D. Saunders, and J. D. Ditmars, 1979. Wintertime Raw-Water Contamination at Chicago's South Water Filtration Plant. JWPCF 51(10):2432-2446.

Michigan Department of Natural Resources, 1979. Five-Year Strategy for Water Quality, Solid and Hazardous Waste Programs. Office of Environmental Planning and Program Coordination, Lansing, Michigan.

Milwaukee Metropolitan Sewerage District, 1979a. COS Recommendations, Decision Matrix Chart (May 10). Milwaukee, Wisconsin.

Milwaukee Metropolitan Sewerage District, 1979b. To Every Citizen of the Milwaukee Metropolitan Area. The Milwaukee Journal, special insert, April 22.

Milwaukee River Technical Study Committee, 1968. The Milwaukee River - An Inventory of Its Problems, an Appraisal of its Potentials. Southeastern Wisconsin Regional Planning Commission, Waukesha, Wisconsin.

Monahan, E. C. and P. C. Pilgrim, 1975. Coastwise Currents in the Vicinity of Chicago, and Currents Elsewhere in Southern Lake Michigan. Department of Computer and Communication Sciences, University of Michigan, Ann Arbor, Michigan.

Rodgers, W. H., 1977. Environmental Law. West Publishing Co., St. Paul, Minnesota, 956 pp. 
Sonzogni, W. C., T. J. Monteith, W. E. Skimin, and S. C. Chapra, 1979. Critical Assessment of U.S. Land Derived Pollutant Loadings to the Great Lakes. U.S. Task D Report, Pollution From Land Use Activities Reference Group (PLUARG), International Joint Commission, Windsor, Ontario, $179 \mathrm{pp}$.

Tarlock, A. D., 1979. Environmental Law: What It Is, What It Should Be. Environ. Sci. Technol. 13(11):1344-1348.

U.S. Environmental Protection Agency (EPA), 1978. Needs Survey: Cost Methodology for Control of Combined Sewer Overflow and Stormwater Discharge. EPA-430/9-79-003.

Ward, P. S., 1978. The Milwaukee Case: Changing the Rules for Water Clean-Up. JWPCF 50(2):188-190. 